\title{
The Suitability of Different Sources of Biofertilizers to Support Sustainability of Organic Vegetables Practice in Bengkulu Province of Indonesia
}

\author{
Merakati Handajaningsih, Usman Siswanto, Teguh Adiprasetyo, Hidayat, Bambang \\ Purnomo, Marwanto, Lisa Nuri
}

\author{
Agroecotechnology Department, Agriculture Faculty, University of Bengkulu. Indonesia. \\ Email: merakati@gmail.com
}

\begin{abstract}
Chili pepper (Capsicum annuum)and pakchoy (Brassica rapa) are among two Indonesian popular vegetables which are different in economical plant part of organs (fruit and leaf) and time to harvest (150 and 40 days after planting). Four different formulas of bio-fertilizers were applied in this experiment to revealed the most appropriate one as major input in vegetable organic cultivation. The experiment was conducted on small scale highland-vegetable farmer of Bengkulu Province of Indonesia. Bio-fertilizer composition incorporated bio-waste of vegetable residues, cow manure, and weeds of surrounding planting area. The dose of bio-fert was 20 tones/ha, sowed evenly on planting beds a week before planting. The experiment showed that bio-fertilizers decomposed from weeds and mixture of weeds, cow manure and veg harvest residues resulted on denser roots during the early plant growth as well as higher yields on pakchoy. Chili pepper plants were more suitable grown on soil incorporated with vegetable harvest residues, cow manure, or weeds but not with mixture of the three materials. Weeds and mixture bio-ferts were found to have higher contents of potassium and phosphor, and slightly high on nitrogen.
\end{abstract}

Key words: bio-fertilizer composition, vegetables, plant growth, yield.

\section{INTRODUCTION}

The increasing intensification of agriculture that began in the early 1900s to the 1940's were marked by the development of large-scale monoculture and the intensive use of chemicals for fertilization, weed control, pest and pathogen. The negative impact generated from agriculture is also increasing especially during the last 3 decades thus leads to the movement of "back to nature agriculture". Meanwhile, the existence of microbes in various types of organic matter and soil have been reported, usually as decomposers. Medium microbes that have a special association with plants, whether they are symbiotic or parasitic, is much more limited and specific. The use of microbial symbionts to stimulate the growth and production of crops such as the effect of the use of mycorrhiza (Phosri et al., 2010) and antagonists of pathogens (Abbasi et al., 2002; Alwang and Miller, 2011) have also been reported.

However, the use of microbes to improve the efficiency of waste decomposition process of organic matter supplied to the agricultural land has not been exposed. Common usage of organic material is as mulch or compost on the field, without any addition of microbes, including those that have been reported from the semi - tropical region and the Sahara desert that has faced very severe erosion (Aggarwal et al., 1997; Bastida et al., 2008). The addition of organic matter can influence the microbial composition of the soil ( Bardgett et al., 2006; Bastida et al., 2008; Bell et al., 2006; Bittman et al., 2005; Federle et al., 1986). Tejada et al. $(2010 ; 2011)$ reported the role of diverse groups of bacteria, especially Bacillus spp., which in addition to increase plant growth and productivity, it also lowers the damage caused by pests and diseases. The addition of beneficial microbes into compost plus or bio-fertilizer, not only improves the growth and yield, but also increases the resistance of plants to pests and diseases (Abbasiet al., 2002; Aseri et al., 2008).

In Indonesia, abundant organic waste may come from material waste, household waste , especially waste and food industries, as well as agricultural waste, plantations and farms. It is recycled but in very low quantity, otherwise it caused pollution problems that are hazardous to the health of animals and humans. In addition, the climatic conditions always favor the development of microbes in almost all areas, the development of multi- microbial -based bio- fertilizer very appropriate thing to do, 
especially when Bio-Fert to be generated can utilize different types of organic wastes. Besides to addressing the problems of waste buildup, organic materials available can be used to fertilize the soil, increase crop productivity and farmers' welfare, as well as value back land that is not fertile due to erosion and mis-management .

Application of fresh organic ingredients or are already composted, including manure is also able to increase the growth and yield (Tejada et al., 2006; Walter et al., 2000 ), because the organic matter or animal waste can improve the physical properties of the soil, the water system, the availability of nutrients for plants and plant production (Aggarwalet al., 1997). Provision of organic materials can also be combined with synthetic fertilizer at lower doses to produce the same high productivity with the use of chemical fertilizers alone. Thus the addition of organic matter is further recommended to reduce the dose of synthetic fertilizers, because in addition to limited supply and inefficiency, excessive $\mathrm{N}$ fertilizer can cause air pollution because of volatilization (Aggarwalet al., 1987).

\section{MATERIALS AND METHODS}

The study was conducted between June 2013 and February 2014 and carried out at Laboratory of the Faculty of Agriculture, University of Bengkulu and farmland located at highland of Rejang Lebong, Bengkulu Province, Indonesia, which is about 800 meter above sea level.

Biofert material produced with crop residues + manure (C), weeds + cow dung (W) and cow manure (M), and the combination of crop residues, weeds, and cow manure (CWM) were applied at doses standard 20 ton/ha on 2 horticultural crops, e.i. chili peppers (Capsicum annuum), pakchoy (Brassica rapa). The research design was randomized complete block with 3 replications. Planting was set on raised bed plots, with each size of $0.80 \mathrm{~m}$ x $5.00 \mathrm{~m}$. Bio-ferts were spread and incorporated into soil evenly all over the beds a week before planting. Silver black plastic mulch was laid down following spreading bio-ferts. Planting holes were punched where plant seedlings were established. Each chili bed consisted of 2 rows, $50 \mathrm{~cm}$ in row planting space, while pakchoy bed consisted of 3 rows per bed within row planting space of $25 \mathrm{~cm}$. Soil and bio-ferts were analyzed for physical and chemical properties, vegetative and generative variables of plants were measured. Mature chilli pepper fruits were harvested 6 times in every 5 days, while pakchoy plants were harvested at once 40 days after planting.

\section{RESULTS AND DISCUSSION}

Laboratory analysis of soil and the 4 types of bio-fertilizer are presented in Table 1 . The highest $\mathrm{pH} 7.7$ was obtained from bio-fert weeds + cowdung. As for the other three types bio-fert $\mathrm{pH}$ values ranged from 7.4 to 7.5. Soil analysis showed lower values of nutrient contents and $\mathrm{pH}$ compared to bio-ferts.

Growth of chili and pakchoy at 2 weeks after planting ( WAP ) were not affected by the type bio-fert applied . Competition occurs when nutrient growth medium in question has become a limiting factor (Salisbury and Ross, 1991). At the beginning of the growth of nutrient availability still meet the initial needs of plants. Besides, this phase is characterized by Vegetative Lag Period in which the plants are slow growing. Pakchoy plants showed different growth responses after 3 WAP. Bio-fert composted from weeds + cowdung (W) or mixture between crop residues, cow-dung and weeds (CMW) supported pakchoy plants for better growth and higher yield per bed (Table 3). The content of Nitrogen in treatment $\mathrm{W}$ and treatment CMW equals to $50 \mathrm{~kg}$ and $52 \mathrm{~kg}$ per hectare respectively. Apparently the yield of organic pakchoy in this study was similar to that of non-organic pakchoy cultivation under application of $70 \mathrm{~kg} \mathrm{~N} / \mathrm{ha}$.

Composition of nutrients as well as microbes incorporated in bio-fert influences the properties medium that may causes different response to plants. Some studies on organic systems demonstrated the response of horticultural crops on various organic fertilizer sources (Handajaningsih et al., 2011; Kochakinezhad et al., 2012). This study revealed that chili pepper was less suitable when grown on bio-fert mixed from crop residues, weeds and cowdung (CMW treatment) as shown on Table 2. At the end of the vegetative growth, the plants treated with vegetable-crop- residues bio-fert performed higher compared to other bio-fert treatments. Fruits as the economic plant organ of chili plants are much supported by dichotomous branches so it implies that the more number of dichotomous branches the 
higher crop yield potential will be. Potassium and Phosphate are plant nutrients that play important roles on flowering and fruiting. The low content of potassium on soil incorporated with CMW bio-fert might deprive the contribution of phosphate to fruit yield and yield components of chili.

Table 1. Laboratory analysis of bio-ferts, soil and biofert- treated soil

\begin{tabular}{lllllllll}
\hline Bio-fert soil & $\mathrm{pH} \mathrm{H}_{2} \mathrm{O}$ & C-Organic & Total N & $\begin{array}{l}\mathrm{P} \\
\text { Bray I }\end{array}$ & $\mathrm{K}$ & $\mathrm{Ca}$ & $\mathrm{Mg}$ & $\begin{array}{l}\mathrm{Mn} \\
(\mathrm{ppm})\end{array}$ \\
\hline & & $(\%)$ & $(\%)$ & $(\mathrm{ppm})$ & $(\mathrm{me} / 100 \mathrm{~g})$ & & \\
Bio. C & 7.4 & 3.46 & 0.24 & 65.3 & 3.89 & 7.65 & 1.94 & 21.13 \\
Bio.M & 7.5 & 3.17 & 0.23 & 61.4 & 3.97 & 9.52 & 1.98 & 24.13 \\
Bio. W & 7.7 & 3.75 & 0.26 & 87.4 & 5.90 & 7.38 & 1.95 & 25.42 \\
Bio.CMW & 7.5 & 3.60 & 0.25 & 89.3 & 4.68 & 8.28 & 2.00 & 17.29 \\
Soil & 5.1 & 2.95 & 0.21 & 29.8 & 0.21 & 2.26 & 0.73 & 6.22 \\
Soil + C & 5.3 & 3.89 & 0.40 & 10.90 & 0.31 & 3.45 & 1.15 & 10.66 \\
Soil + M & 5.3 & 3.72 & 0.34 & 12.30 & 0.29 & 3.11 & 1.14 & 8.96 \\
Soil + W & 5.3 & 4.36 & 0.36 & 10.50 & 0.27 & 3.20 & 1.05 & 9.36 \\
Soil + CMW & 5.2 & 3.58 & 0.33 & 11.17 & 0.25 & 2.98 & 0.91 & 10.29 \\
& & & & & & & & \\
\hline
\end{tabular}

Table2. Mean growth and yield of chili pepper as affected by types of Bio-fert

\begin{tabular}{cccccc}
\hline Treatment & $\begin{array}{c}\text { Plant height } \\
(\mathrm{cm})\end{array}$ & $\begin{array}{c}\text { Number of } \\
\text { dichotomous }\end{array}$ & $\begin{array}{c}\text { No. of fruit } \\
\text { /plant }\end{array}$ & $\begin{array}{c}\text { Weight per fruit } \\
(\mathrm{g})\end{array}$ & $\begin{array}{c}\text { Fruit weight per } \\
\text { plant }(\mathrm{g})\end{array}$ \\
\hline $\mathrm{C}$ & $53.28 \mathrm{~b}$ & 89.3 & 34.63 & $1.70 \mathrm{~b}$ & 68.33 \\
$\mathrm{M}$ & $51.83 \mathrm{~b}$ & 71.8 & 35.77 & $1.61 \mathrm{~b}$ & 60.37 \\
$\mathrm{~W}$ & $51.72 \mathrm{~b}$ & 53.73 & 35.80 & $1.63 \mathrm{~b}$ & 72.46 \\
$\mathrm{CMW}$ & $44.77 \mathrm{a}$ & 47.87 & 29.07 & $1.26 \mathrm{a}$ & 56.00 \\
\hline
\end{tabular}

Table 3.Mean growth and yield of pakchoy as affected by types of Bio-fert

\begin{tabular}{ccccc}
\hline Treatment & $\begin{array}{c}\text { Yield/ bed } \\
(\mathrm{g})\end{array}$ & $\begin{array}{c}\text { Plant height } \\
(\mathrm{cm})\end{array}$ & Leaf number & Fresh weight/plant $(\mathrm{g})$ \\
\hline $\mathrm{C}$ & 850.00 & 15.88 & 7.266 & 55.36 \\
$\mathrm{M}$ & 916.67 & 14.20 & 5.633 & 35.04 \\
$\mathrm{~W}$ & 1750.00 & 16.14 & 5.433 & 59.71 \\
$\mathrm{CWM}$ & 1883.33 & 23.38 & 5.933 & 59.25 \\
\hline
\end{tabular}

\section{CONCLUSION}

The conclusion of this research was that bio-fert composted from weeds and cowdung or bio-fert composted from mixture of crop harvest residues, cowdung and weeds had better effect ongrowth and yield of organic pakchoy. Nevertheless, chili pepper plants were more suitable grown on soil incorporated with bio-fert processed from weeds+ cowdung, or crop harvest residues + cowdung, or cow dung alone.

\section{ACKNOWLEDGEMENT}

We greatly thanks and honors to University of Bengkulu for supporting this research fund through Higher Education Prospective Research Grant the Year of 2013.

\section{REFERENCES}

Abbasi, P.A., J. Al-Dahmani, F. Sahin, H.A.J. Hoitink, and S.A. Miller. 2002. Effect of compost amendments on disease severity and yield of tomato in conventional and organic production systems. Plant Disease 86, 156-161.

Aggarwal, R.K., P. Kumar, and J.F. Power. 1997. Use of crop residue and manure to conserve water and enhance nutrient availability and pearl millet yields in an arid tropical region. Soil and Tillage Research (41): 43-51. 
Alwang, J. and S. Miller. 2011. Toward IPM packages for Latin America and the Carribean region. Presentation at APS-IAPPC Joint Meeting, Honolulu, Florida.

Aseri, G.K., N. Jain, J. Panwar, A.V. Rao, and P.R. Meghwal. 2008. Biofertilizers improve plant growth, fruit yield, nutrition, metabolism and rhizosphere enzyme activities of Pomegranate (Punica granatum L.) in Indian Thar Desert. Scientia Horticulturae 117: 130-135.

Bardgett, R.D., P.J. Hobbs, and A. Frostegard. 1996. Changes in soil fungal: bacterial biomass ratios following reductions in the intensity of management of an upland grassland. Biol. Fertil. Soils 22: 261-264.

Bastida, F., E.Kandeler, J.L. Moreno, M. Ros, C. García, and T.Hernández. 2008. Application of fresh and composted organic wastes modifies structure, size and activity of soil microbial community under semiarid climate. Appl. Soil Ecol. 40: 318-329.

Bell, J.M., C.A. Robinson, and R.C. Schwartz. 2006.Changes in soil properties and enzymatic activities following manure applications to a rangeland. Rangeland Ecol. Manage. 59: 314-320.

Bittman, S., T.A. Forge, and C.G. Kowalenko. 2005. Responses of the bacterial and fungal biomass in a grassland soil to multi-year applications of dairy manure slurry and fertilizer. Soil Biol. Biochem. 37: 613-623.

Federle, T.W., D.C., Dobbins, J.R. Thornton-Manning, and D.D. Jones. 1986. Microbial biomass, activity, and community structure in subsurface soils. Ground Water 24: 365-374.

Handajaningsih, M., Y.H. Bertham, and D.W. Ganefianti. 2011. Pemberdayaan Kawasan Pesisir Berbasis Budidaya Cabai Organik di Propinsi Bengkulu. Laporan Penelitian Universitas Bengkulu.

Kochakinezhad, H., Gh. Peyvast, A.K. Kashi, J.A. Olfati, and A. Asadii. 2012. A comparison of organic and chemical fertilizers for tomato production. J. of Organic Systems 7(2): $14-25$.

Obi, M.E. and P.O. Ebo. 1995. The effects of organic and inorganic amendments on soil physical properties and maize production in a severely degraded sandy soil in southern Nigeria. Biosci. Technol. 51: 117-123.

Phosri, C., A. Rodriguez, I.R. Sanders, and P.Jeffries. 2010. The role of mycorrhizas in more sustainable oil palm cultivation. Agriculture, Ecosystems and Environment 135: 187-193.

Salisbury,F.B. and C.W. Ross. 1991. Plant Physiology. Wadsworth Publ. Co. California.

Tejada, M., C. Benitez, I. Gomez, J. Parrado. 2011. Use of biostimulants on soil restoration: Effects on soil biochemical properties and microbial community. Applied Soil Ecology 49 (1): 11- 17.

Tejada, M., M.T. Hernández, and C. García. 2006. Application of two organic amendments on soil restoration: effects on the soil biological properties. J. Environ. Qual. 35(4): 1010-1017.

White, C.S., S.R. Loftin, and Aguilar. 1997. Application of biosolids to degraded semiarid rangeland: nine year responses. J. Environ. Qual. 26: 1663-1671. 